Annals of Warsaw University of Life Sciences - SGGW

Land Reclamation No 49 (2), 2017: 129-140

(Ann. Warsaw Univ. of Life Sci. - SGGW, Land Reclam. 49 (2), 2017)

\title{
Analysis of technical feasibility of status improvement the river and valley environment on the example of selected objects
}

\author{
ZBIGNIEW POPEK, MICHAŁ WASILEWICZ
}

Faculty of Civil and Environmental Engineering, Warsaw University of Life Sciences - SGGW

\begin{abstract}
Analysis of technical feasibility of status improvement the river and valley environment on the example of selected objects. In order to improve the status of rivers and valleys environment, protective measures are often insufficient - technical measures are also required. The paper presents two concepts of technical solutions proposed for the sections of the Świder and Rawka rivers, lying within the boundaries of natural protected areas. Due to the purpose of the project, the type of planned works, their scope and the expected final result, these concepts may be typical examples of river restoration and river and valley revitalization. The proposed activity on the Świder river is to inhibit erosion of the deep riverbed, by reconstructing the former natural estuary. Therefore, these actions can be classified as typical river restoration. In the case of the Rawka river, the aim is to revitalize the river and the valley, by ensuring the ecological continuity of the riverbed and improving the status of valley habitats.
\end{abstract}

Key words: natural protected areas, small lowland rivers, river renaturalization, river revitalization, environment status improvement, technical measures

\section{INTRODUCTION}

The main objective of the river restoration is to improve the abiotic conditions and the status of the river environment and habitats associated with it. Among the detailed objectives of the planned restoration activities can be mentioned (Żelazo and Popek 2014):
- biodiversity and natural values enhancement;

- improvement of the ecological status of the river;

- the river ecosystem continuity assurance;

- enhancement of the retention capacity of rivers and valleys;

- landscaping, recreational and tourist values improvement;

- rational economic use of rivers and valleys.

River restoration objectives are achieved through appropriate actions that can be carried out in four areas (Fig. 1): riverbed, river bank zone, valley floodplain, tributary and catchment area. Typically, river restoration does not cover all of the mentioned areas and is limited to the selected one or two zones and a few specific actions.

In turn, the aim of revitalizing the river and/or its valley is to improve the ecological status of habitats that can be achieved without the need to significant changes in the morphological characteristics of the river bed. The revitalization of the river will therefore include activities carried out to a lesser extent than in the case of river restoration.

The selection of technical measures must be adjusted to the nature of the river and must consider a number of constraints arising from the current economic uses 


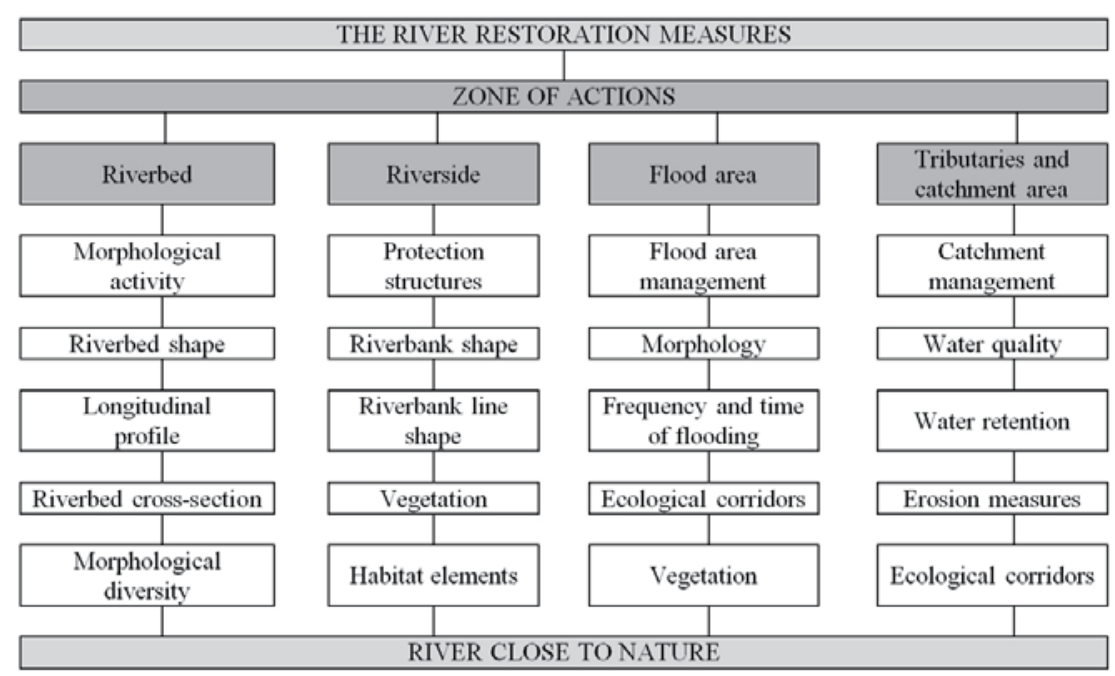

FIGURE 1. The river restoration measures (Kern 1992 - scheme partly modified)

of the river and existing infrastructure (bridges, water intake, waterways, flood protection facilities, etc.). However, the most important element, which have to be considered in developing the concept is the diagnosis of the current state of the river and its valley natural environment and the scope of actions necessary to improve it. The influence of earlier anthropogenic transformations (river regulation, hydrotechnical development) on the natural environment should be also taken into account. On the one hand, it could cause negative changes in river channel morphology, on the other - create new, not rare valuable natural habitats. Analyzes in this regard are particularly important for rivers flowing through the natural protected areas. The paper presents two conceptual solutions (Fig. 2): the river restoration of the estuary section of the Świder river and revitalization

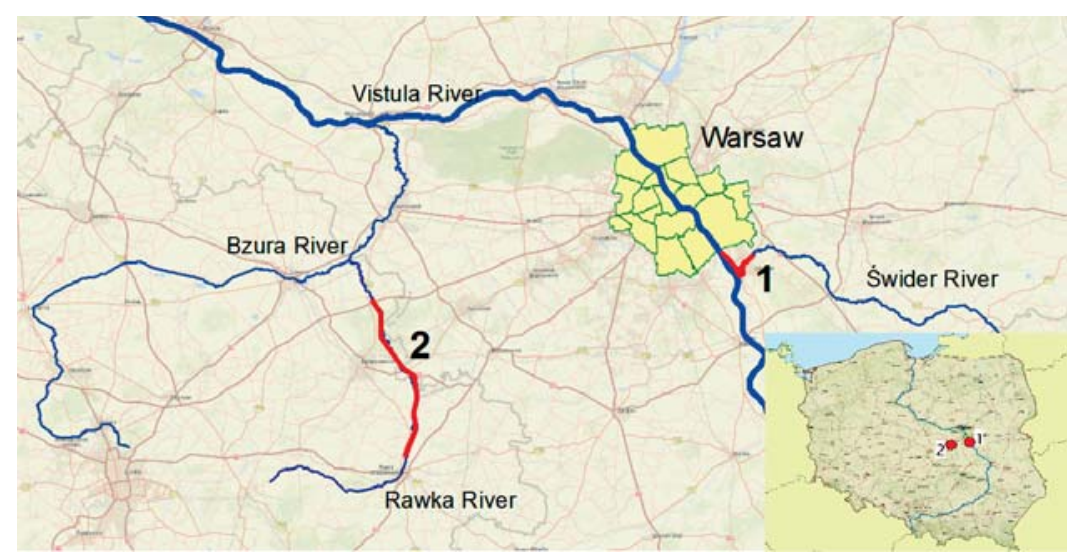

FIGURE 2. The location of the study area 
of the middle part of the Rawka river and its valley, which are located in the areas subject to legal protection.

\section{MATERIAL AND METHODS}

The concept of technical solutions for the analyzed river sections was elaborated on the basis of chamber works and field studies, which included:

- literature review and collection of information from unpublished materials (reports, projects, etc.) on analyzed river sections;

- analysis of archival maps and aerial photographs from different periods, made in ArcGIS program;

- analysis of archival and current cross sections and longitudinal profile of the river;

- field studies to assess: the ecological status of the river and valley environment, the technical condition of hy draulic structures and the possibility of implementing pre-proposed technical solutions.

\section{RESEARCH OBJECTS AND CONCEPTUAL SOLUTIONS}

\section{The Świder river}

The Świder river is the right-bank tributary of the Vistula river, whose estuary is located at $\mathrm{km} 491$ of the waterway (Fig. 3), i.e. about $10 \mathrm{~km}$ above the southern border of Warsaw City. The length of the Świder river is $94.5 \mathrm{~km}$ and the catchment area is $1,149.3 \mathrm{~km}^{2}$ (Czarnecka 2005). The mouth of the Świder river is located partly in the Natura 2000 area of the Vistula River Central Valley and near the Vistula nature reserve: Świderskie Islands and Zawadowskie Islands (Fig. 4).

The channel improvement was carried out on the estuary section of the Świder river in the 1970s. This work involved the construction of a road bridge on the route of the Otwock ring road (Moruś 2015). The morphology of the Świder river was characterized by a braided river before the river regulation. There were numerous of moving sandy bars and islands, and its mouth was located at $496.5 \mathrm{~km}$ of

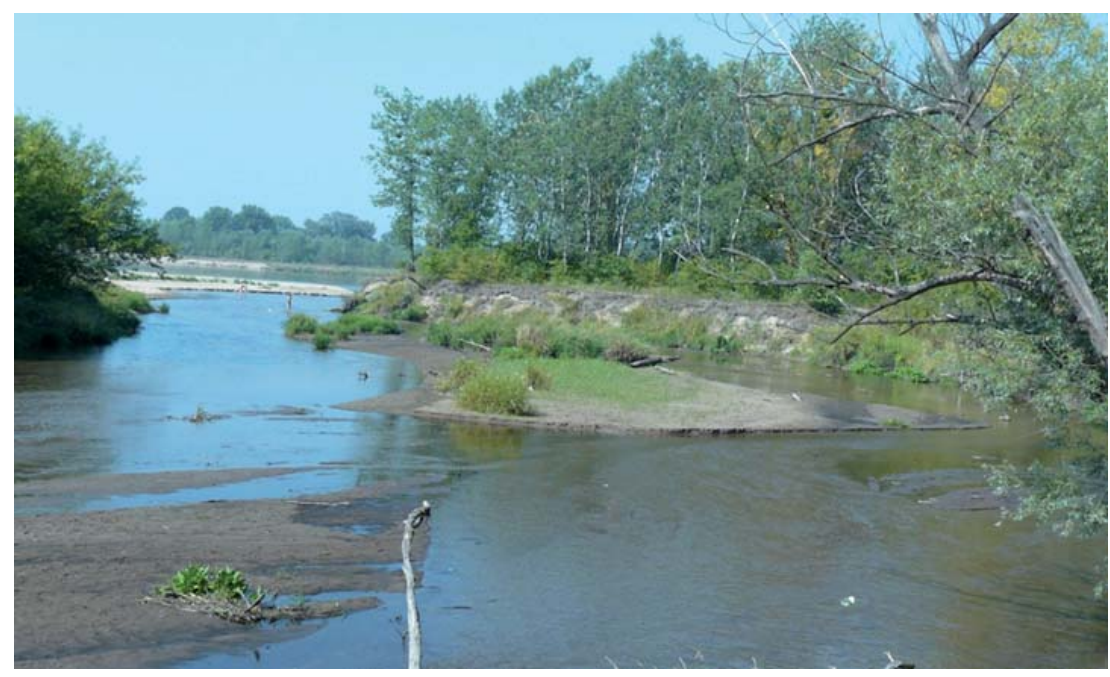

FIGURE 3. The view of the Świder river mouth into the Vistula river (Moruś 2015) 


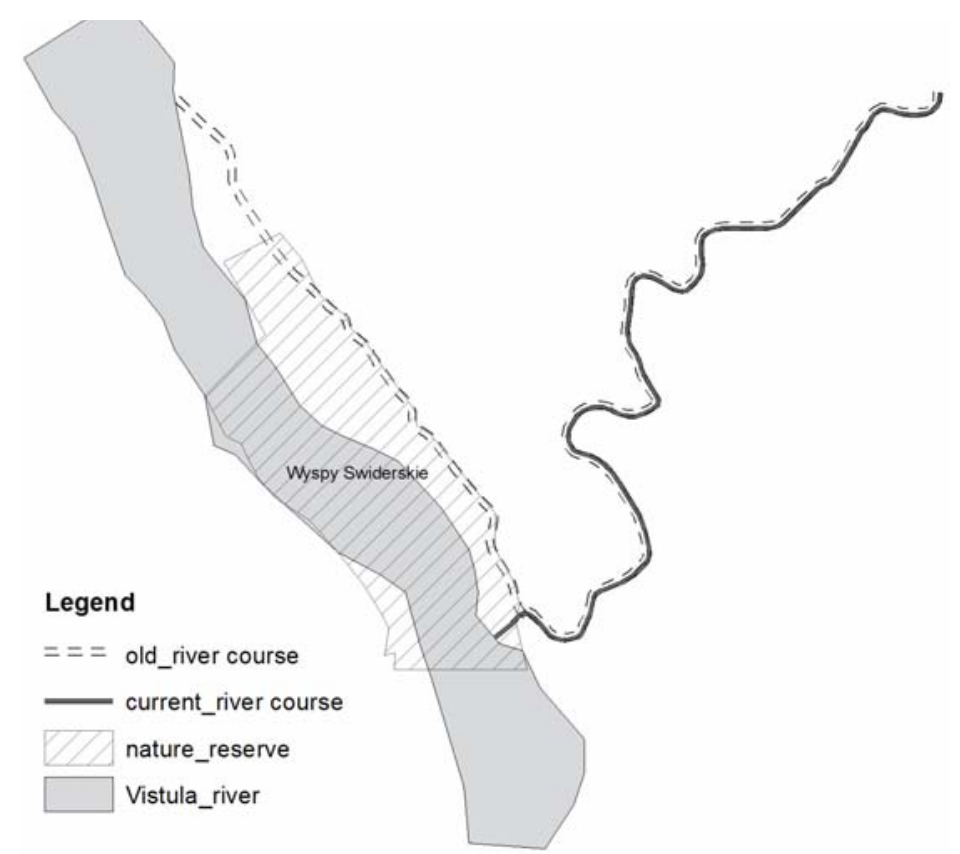

FIGURE 4. The aerial view of the current estuary of the Świder river with visible sediment deposits in the Vistula riverbed (www.geoportal.gov.pl)

the Vistula river (Fig. 5). As a result of river regulation, the length of the river was reduced by approximately $5.5 \mathrm{~km}$, which resulted in a gradual increase of the longitudinal riverbed slope from the initial value of $0.55 \%$ in 1966 to $1.05 \%$ o in 2013 (Fig. 6). The increase of the water surface level's slope nearly twice as more as it was in past resulted in increasing of the water flow velocity, which in turn caused riverbed deep erosion the bottom elevations in the thalweg fell by $2-2.5 \mathrm{~m}$. There were also morphological changes of the river type - the Swider riverbed from the relatively shallow and wide transformed into a single channel river, with a deeply cut and narrow cross-section. Lowering the bottom also caused adverse negative changes in the river valley - decreased the frequency of flood flows and the groundwater level. These changes caused the disappearance of lateral arms of rivers, old river beds, ponds and wetlands, as well as changes in banks and valley vegetation.

The objectives of the river restoration project for estuary section of the Świder river are as follows:

- inhibition of riverbed erosion and gradual raising of the river bottom level;

- reconstruction the old morphology of the braided river;

- raising the level of groundwater in the valley;

- reduction of degradation and gradual increase of habitat diversity in the valley;

- enhancement of the attractiveness of the tourist and recreational estuary section of river; 


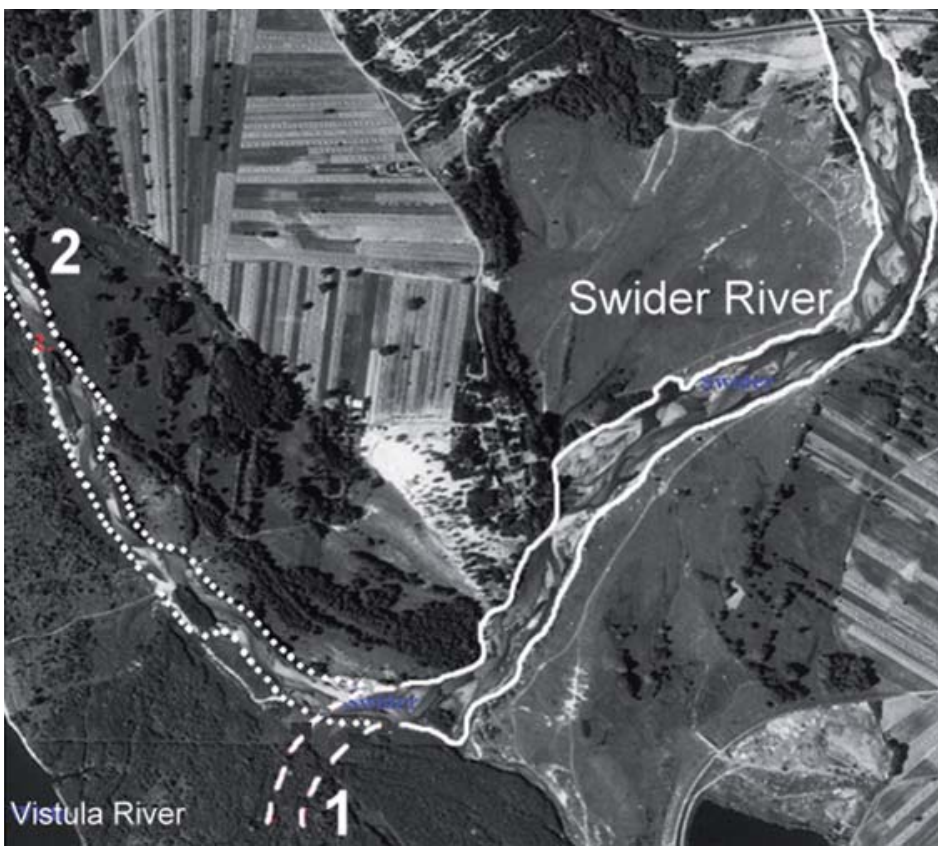

FIGURE 5. The aerial view of old estuary (2) of the Świder river with visible multi-thread braided channel and location of present estuary (1)

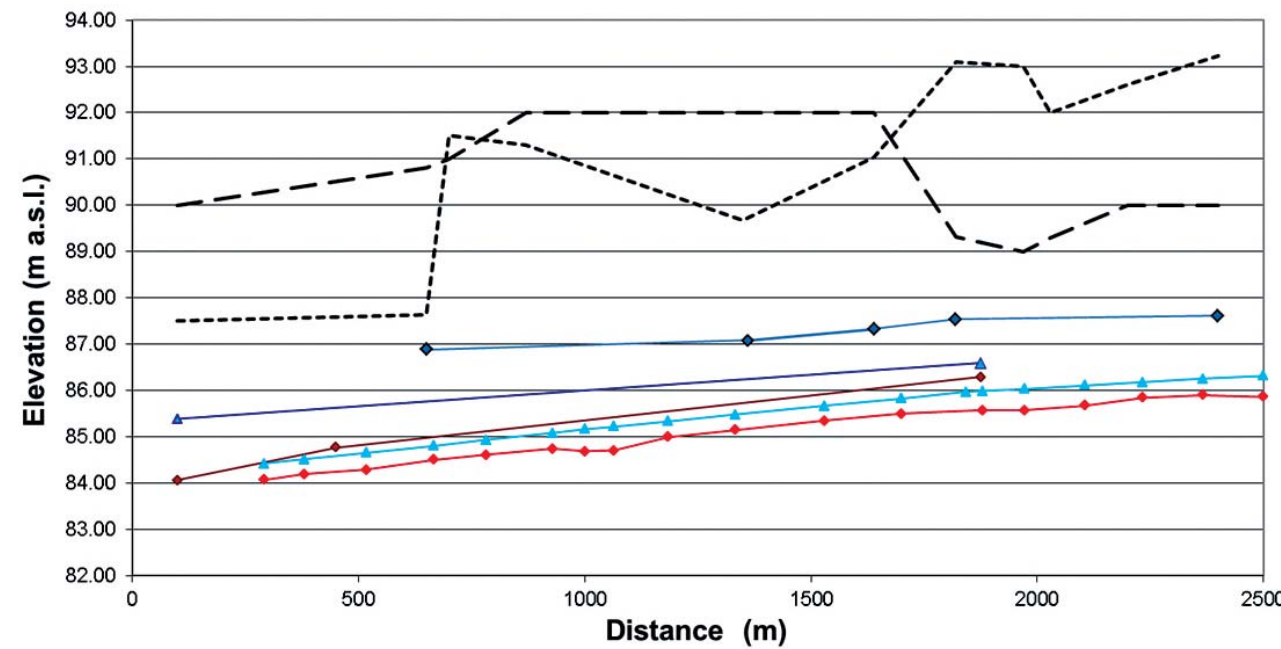

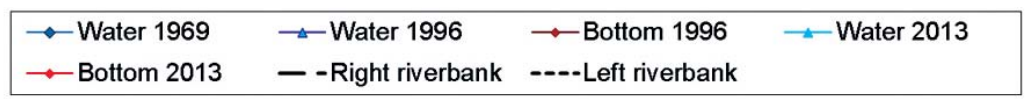

FIGURE 6. The longitudinal profile changes on of the Świder river estuary section (Moruś 2015) 
The proposed technical solutions include (Fig. 7):

- reconstructing the former riverbed location (which partly preserved in the form of oxbows) and the mouth of the Świder river to the Vistula river;

- closing of the present mouth of the Swider river to the Vistula river with a fixed gabion weir, which should be maintain the flow distribution so as to keep the minimum discharges in both branches - old and new one of the Świder river.

The implementation of the river restoration project will also contribute to the conservation of the nature reserve Świderskie Islands, because the recreated part of the Swider river will be the natural boundary of the reserve. This action will reduce or even completely eliminate the current influxes of domestic animals and humans in the nature reserve.

\section{The Rawka river}

The Rawka river is located in the Vistula river basin, is the right tributary of the Bzura river in $\mathrm{km} \mathrm{43}$. The total area of the Rawka river catchment is $1,191.7 \mathrm{~km}^{2}$, while the river length is $105.1 \mathrm{~km}$ (Czarnecka 2005). The analyzed middle section of the river has the character of a natural, mostly single channel meandering lowland river (Fig. 8). In the past, there were many mills weirs built along the Rawka river. Between years 1800 and 1880 there were 18 weirs in the $38.5 \mathrm{~km}$ long section of the river, of which 9 have been preserved up till now (Fig. 9).

Despite the long-lasting hydrotechnical development, the Rawka river and its valley have very high natural values. It was the basis in establishing of several protected areas (Kiczyńska 2006). The oldest one is the Rawka River Reserve established in 1983, which aims to pre-

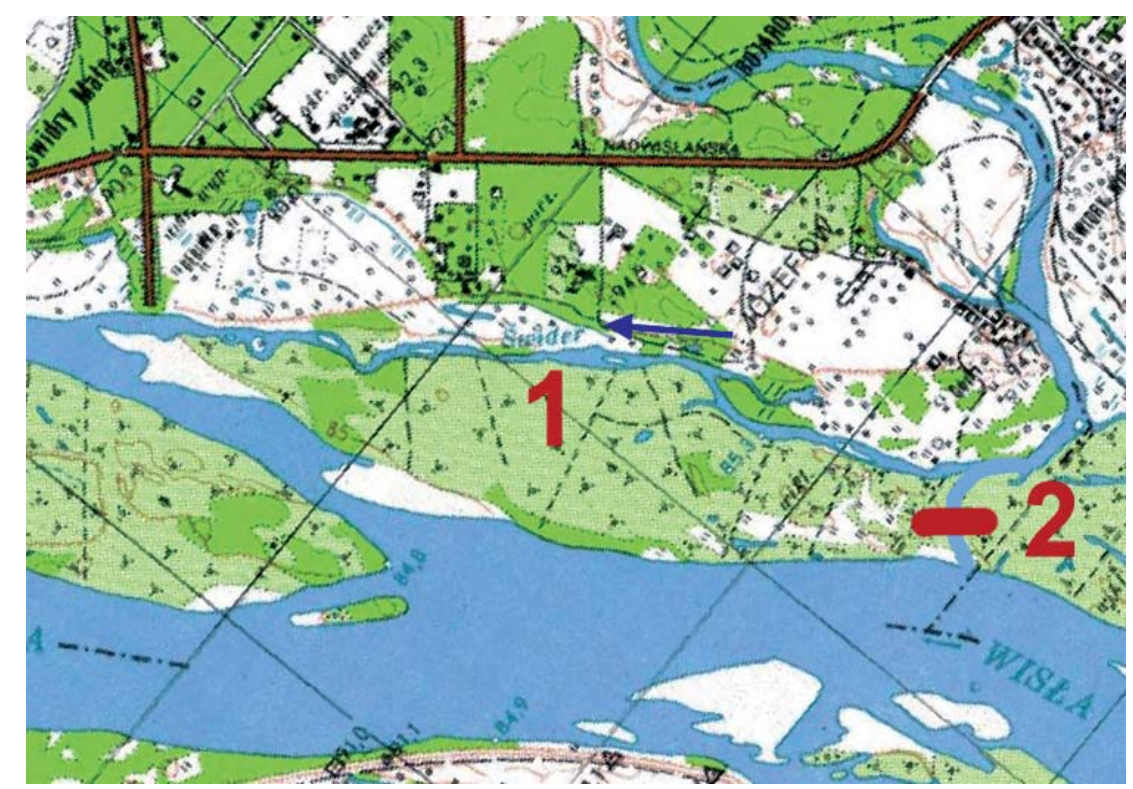

FIGURE 7. The Świder river project - proposed technical solution marked as follow: 1 - restoration of the old riverbed, 2 - gabion weir for closing current river mouth (Moruś 2015) 


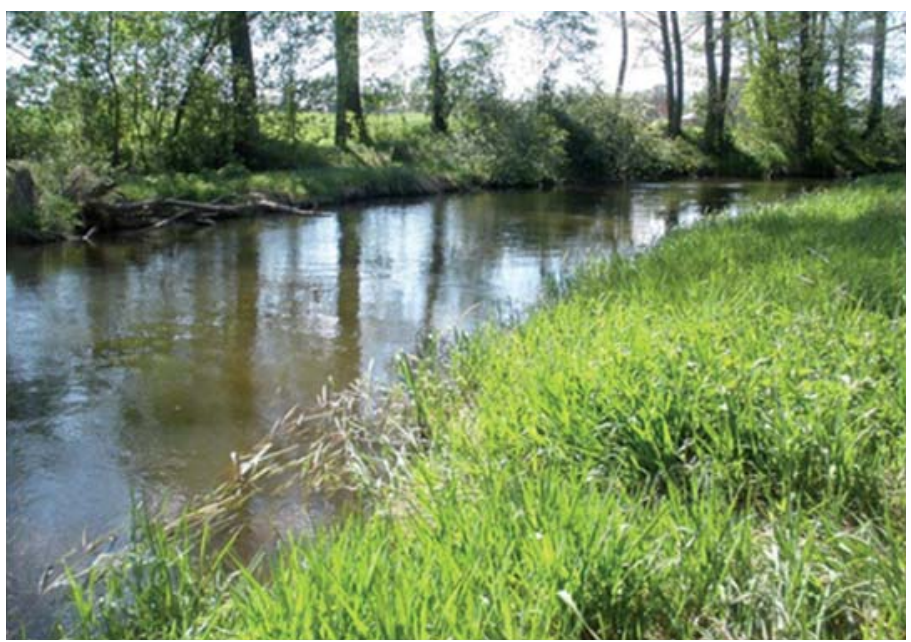

FIGURE 8. The view of the Rawka riverbed (photo Anna Opalińska)

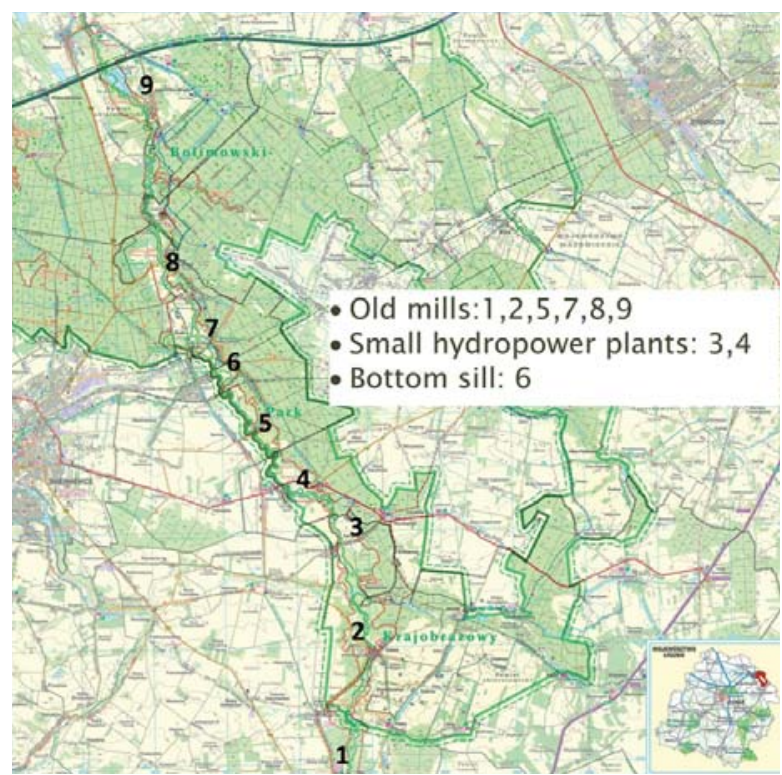

FIGURE 9. The location of damming structures along the Rawka river on the section of the Bolimowski Landscape Park

serve the natural state of the river and valley landscape, as well as the habitat of protected species of fauna and flora. The nature reserve covers the entire length of the riverbed, from the source to the estuary, along with a 10 -meter wide coastal strip and estuary sections of the tributaries. Established in 1986, the Bolimowski Landscape Park (BLP) covers the lower and middle Rawka river (area of over 23 thousand ha). Moreover, since 1986 in this region there is Bolimowsko-Radzie- 
jowski Protected Landscape Area, covering an area of over 34 thousand ha. The region of Natura 2000 the Rawka River Valley was established in 2008 as the Special Area for Conservation of Species - it has an area of about 2.5 thousand ha, which covers $65 \%$ of the BLP area. The territory is intended to protect valuable natural habitats such as: old river beds, natural eutrophic water bodies, flooded muddy river banks, willow, poplar and ash forests and spring algae (Pytliński 2015). In the neighbourhood of the analyzed Rawka river section, there are also two other Natura 2000 sites: Grabianka - including the Grabianka river with the valley, and the Żukowskie Meadow - moist and fresh meadows and pastures (the most valuable and best kept in central Poland), with willow bushes, and ponds, located on the edge of the Bolimowski Forest.

The high natural-landscape value of the analyzed area results, among other things, from the long-term influence of damming structures which shape the habitat conditions both in the river bed and its valley. Most of the nine existing mill weirs lost their original damming functions and have been damaged or partially destroyed. Only two weir structures are in good technical condition since the old mills were rebuilt to small hydroelectric power plants. Of the remaining seven weirs, two require a complete reconstruction, while five - only renovation (Fig. 10).

The gradual destruction of the majority of mill weirs resulted in lowering of water level in the riverbed and the ground along on the large sections of the Rawka river. This affected the ecological status of valley habitats, such as riparian for- ests, meadows, pastures, and led to the disappearance of ponds, old river beds and wetlands. On the other hand, damming structures have a negative impact on some animal species (especially for migratory fishes), because they need the undisturbed connectivity of the river bed to the free migration (Amoros and Roux 1988, Nilsson et al. 2005, McLaughlin et al. 2006). According to the river continuum concept the whole river ecosystem is disturbed by this kind of structures, mainly by destroying the natural equable zonation (Vannote et al. 1980). Therefore, the goals of technical actions should be pointed out to improve the ecological status of the Rawka river bed and the valley as follow:

- protection and improving the composition of the fish species by ensuring the ecological continuity of the river;

- improving the condition and increasing of biodiversity of the river and valley habitats, by restoring the former water level in the river bed and raising the groundwater level in the valley;

- increasing water retention in the river bed and in the valley area, which will improve the humidity conditions during the low-flow periods.

Suggested technical solutions include following actions:

- renovation and adaptation of existing two mill bypass channels to restore the conditions for fish migration (Fig. 11);

- construction of new fish migration channels in the area of three weirs, by merging the Rawka river channel with the estuary sections of the smaller streams - tributaries of the Rawka river (Fig. 12); 


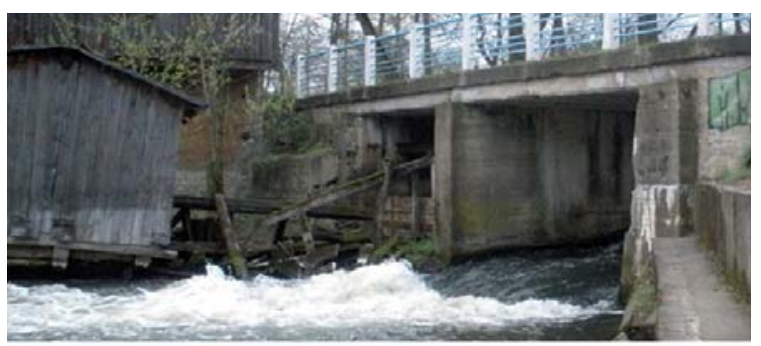

The old mill in Ruda village ( $\mathrm{km} 30$ ).

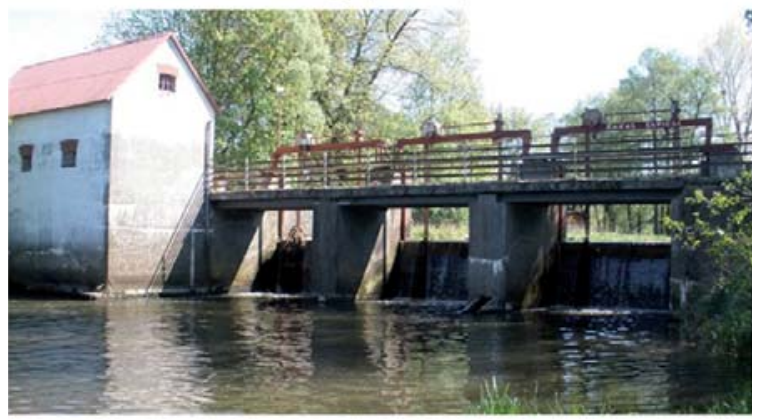

Small hydropower plant in Kamion village ( $\mathrm{km} 37.8)$.

FIGURE 10. Views of some damming structures in the analyzed section of the Rawka river (photo Anna Opalińska)

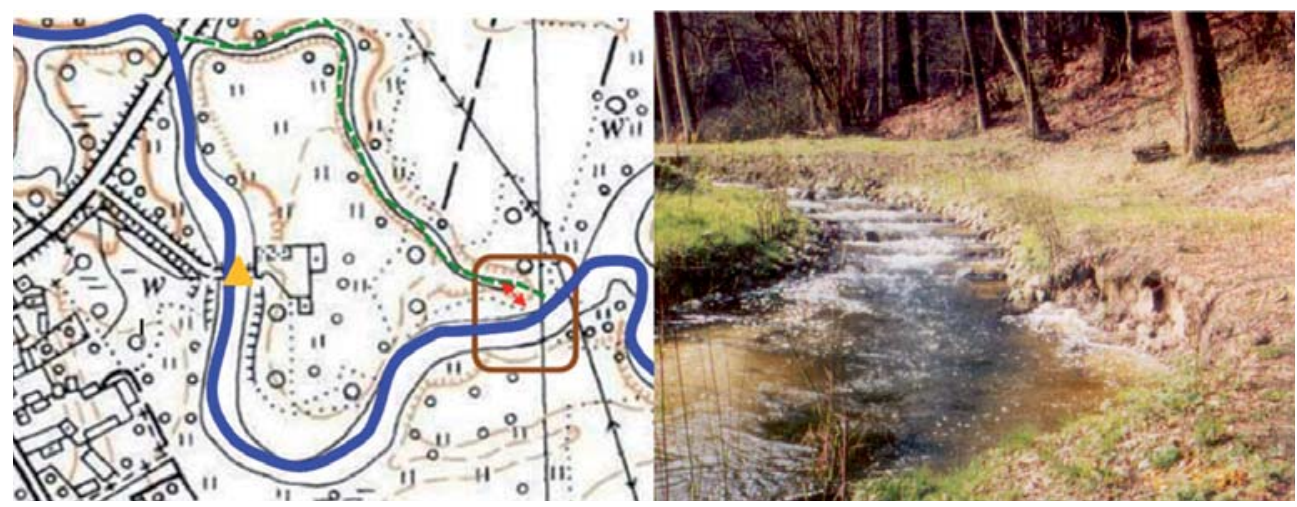

FIGURE 11. The conception of old mill bypass channels, adaptation (black dotted line) for fish migration: $\mathrm{a}$ - the area near Kamion hydropower plant (grey triangle), $\mathrm{b}$ - fish migration channel at the Seifert mill in Germany (WWF 2016)

- construction of three damping steps of $0.5-1.0 \mathrm{~m}$ high with rocky fishpass (Fig. 13).

The results of a similar study (Larinier and Travade 1999, Nakamura et al. 2014), confirm the positive ecologi- cal effects (bringing back the fish migration, the return of species that have vanished, the development of valley habitats). Similar effects in the Rawka river case study may appear with high probability. 


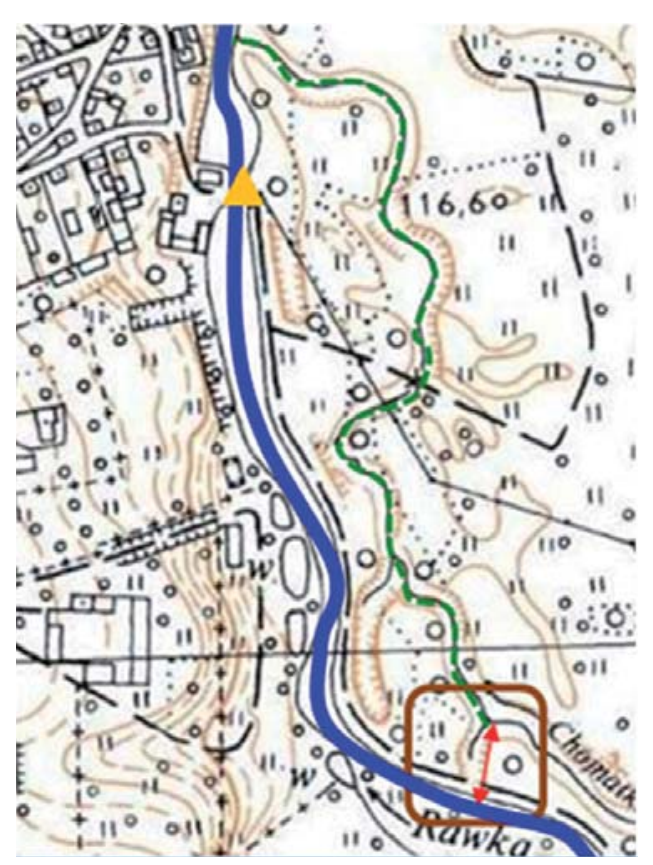

FIGURE 12. The adaptation of the estuary section of the Chojnatka riverbed for fish migration channel near hydropower plant in Suliszew ( $\mathrm{km}$ 42.9)

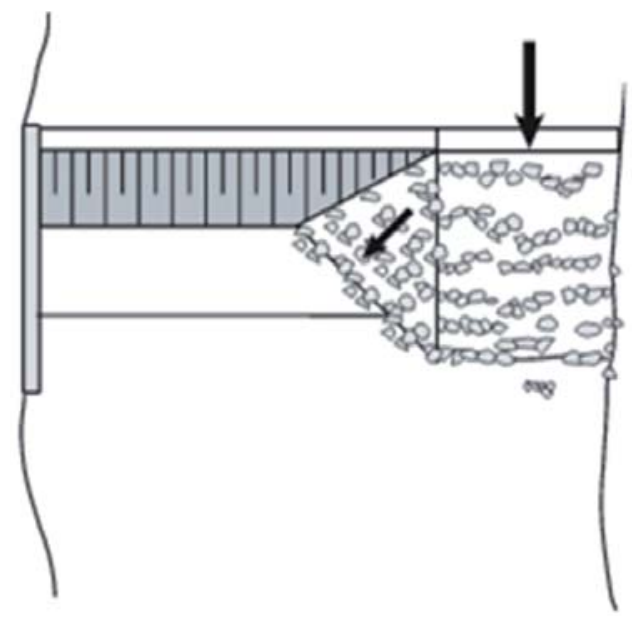

FIGURE 13. The scheme of small bottom sill $0.5-1.0 \mathrm{~m}$ height, combined with the stone-cascade fish pass (WWF 2016)

\section{SUMMARY AND CONCLUSIONS}

1. In the river restoration or river revitalization projects, the range of required technical measures must be adapted to the exact objectives of the project, on the one hand, and on the other, to take into account existing water and river infrastructure, as well as a number of constraints arising from the current economic uses of the river and the valley.

2. An important aspect in the planning of technical activities in a river and valley is the current state of the natural environment. This condition usually results from specific anthropogenic effects, but not always of a negative nature. In case of rivers located in protected areas, consideration should be given to the nature conservation objectives and what is also important, whether full river habitat conservation would be possible in the case of full river restoration.

3. The concept of activities proposed for the estuary section of the Świder river can be classified as typical river restoration projects, which aims to inhibit erosion of the deep river bed by reconstructing the old route and the nature characters of river morphology. The reconstruction of the former riverbed will also result in the creation of a natural boundary of the Świderskie Islands reserve, limiting the possibility of domestic animals and humans influxes. 


\section{REFERENCES}

AMOROS C., ROUX A.L. 1988: Interaction between water bodies within the floodplains of large rivers: function and development of connectivity. Münstersche Geographische Arbeiten 29.1, 125-130.

CZARNECKA H. (Ed.) 2005: Atlas podziału hydrograficznego Polski. Instytut Meteorologii i Gospodarki Wodnej, Warszawa.

KICZYŃSKA A. 2006: Plan ochrony Bolimowskiego Parku Krajobrazowego na lata 2008-2027. Narodowa Fundacja Ochrony Środowiska, Warszawa.

KERN K. 1992: Restoration of lowland rivers: the German experience. In: P.A. Carling, G.E. Pett (Eds), Lowland floodplain rivers. Geomorphological perspectives. John Wiley and Sons, Chichester.

LARINIER M., TRAVADE F. 1999: The development and evaluation of downstream bypasses for juvenile salmonids at small hydroelectric plants in France. In: M. Odeh (Ed.), Fish Passage Technology. American Fisheries Society, Bethesda, Maryland, USA, 25-42.

McLAUGHLIN R.L., PORTO L., NOAKES D.L., BAYLIS J.R., CARL L.M., DODD H.R., GOLDSTEIN J.D., HAYES D.B., RANDALL R.G. 2006: Effects of low-head barriers on stream fishes: taxonomic affiliations and morphological correlates of sensitive species. Can. J. Fish. Aquat. Sci. 63 (4), 766-779.

MORUŚ S. 2015: Koncepcja renaturyzacji ujściowego odcinka rzeki Świder. MSc thesis. Katedra Inżynierii Wodnej, SGGW, Warszawa [manuscript].

NAKAMURA F., ISHIYAMA N., SUEYOSHI M., NEGISHI J.N., AKASAKA T. 2014: The significance of meander restoration for the hydrogeomorphology and recovery of wetland organisms in the Kushiro River, a lowland river in Japan. Restoration Ecol. 22 (4), 544-554.
NILSSON C., REIDI C.A., DYNESIUS M., REVENGA C. 2005: Fragmentation and flow regulation of the world's large river systems. Science 308 (5720), 405-408.

OPALIŃSKA A. 2017: Koncepcja niebieskiego korytarza ekologicznego wzdłuż doliny rzeki Rawki na terenie Bolimowskiego Parku Krajobrazowego. MSc thesis. Katedra Inżynierii Wodnej, SGGW, Warszawa [manuscript]

PYTLIŃSKI S. 2015: Bolimowski Park Krajobrazowy. Zespół Parków Krajobrazowych Województwa Łódzkiego, Łódź.

VANNOTE R.L., MINSHALL G.W., CUMMINS K.W., SEDEL J.R., CUSHING C.E. 1980: River continuum concept. Can. J. Fish. Aquat. Sci. 37 (1), 130-137.

WWF 2016: Przepławki dla ryb - projektowanie, wymiarowanie, monitoring. Fundacja WWF Polska, Warszawa.

ŻELAZO J., POPEK Z. 2014: Podstawy renaturyzacji rzek. Wydawnictwo SGGW, Warszawa.

Streszczenie: Analiza skuteczności poprawy stanu ekologicznego rzek i dolin środkami technicznymi na przyktadzie wybranych obiektów. W celu poprawienia stanu ekologicznego rzek i ich dolin zastosowanie ochrony prawnej często jest niewystarczające - wymagane są również środki techniczne. W artykule przedstawiono dwie koncepcje rozwiązań technicznych proponowanych dla odcinków rzek Świder i Rawki, leżących w granicach obszarów chronionych. Z uwagi na cel projektu, rodzaj planowanych prac, ich zakres oraz oczekiwany efekt końcowy działania te mogą stanowić typowe przykłady renaturyzacji rzeki oraz rewitalizacji rzeki i jej doliny. Proponowana działania na rzece Świder mają na celu zahamowanie erozji głębokiego koryta poprzez rekonstrukcję dawnego naturalnego ujścia rzek. Działania te można więc zaklasyfikować jako typową renaturyzację rzeki. W przypadku rzeki Rawki cele proponowanych działań obejmują rewitalizację rzeki i jej doliny poprzez zapewnienie ciagłości ekologicznej koryta, a także poprawienie stanu siedlisk dolinowych poprzez odbudowę dawnych piętrzeń młyńskich. 
MS received June 2017

\section{Authors' address:}

Zbigniew Popek, Michał Wasilewicz

Katedra Inżynierii Wodnej

Wydział Budownictwa i Inżynierii Środowiska

SGGW

ul. Nowoursynowska 159, 02-776 Warszawa

Poland

e-mail: zbigniew_popek@sggw.pl

michal_wasilewicz@sggw.pl 